\title{
POZNÁMKY K OPEVNĚNÍ MĚSTA VYŠKOVA
}

\author{
MIROSLAV PLAČEK
}

\begin{abstract}
Abstrakt: Město Vyškov bylo nejvýš lehce hrazeným hospodářským centrem skupiny biskupských statkỉ a lén v okolí. Jelikož je roku 1423 zničil útok husitů, hradby vyrostly při obnově zhruba od roku 1440 a napojily se na biskupský hrad (pozdějši zámek). Opevnění z předhusitské doby bez archeologických výzkumů neznáme. Pohusitské se skládalo z hlavni hradby se třemi branskými věžemi a predbraními. Parkán chyběl a až v 17. století vznikal na valu mezi zdvojenými přikopy prstenec sypané fortifikace. Přikopem na jihu protékal potok, na severovýchodè ztěžovala př́stup k městu řeka Haná a na jihovýchodě chránil město rybník. K likvidaci opevnéní došlo v 19. století.
\end{abstract}

Klíčová slova: město - husitské války - hradby - př́kopy - biskupský hrad-historické plány - veduty.

\section{Notes on the Fortification of the Town of Vyškov}

Abstract: The town of Vyškov was a lightly fortified economic centre of a group of episcopal estates and fiefs in the area. The town was destroyed by a Hussite attack in 1423, and was restored together with town walls that adjoined a bishop's castle (later a chateau) approximately after 1440. The fortification from the preHussite era is unknown as no archaeological research took place. The post-Hussite fortification consisted of a main town wall with three gate towers and defence areas in front of them. There was no bailey, and a ring of an earthwork fortification only came into existence on a rampart between double moats as late as the 17th century. A stream flowed through the moat in the south, while in the north-east the access to the town was obstructed by the Hana River and in the south-east it was protected by a pond. The fortification ceased to exist in the 19th century.

Key words: town - Hussite wars - town walls - moats - bishop's castle - historical plans - vedutas.

První písemnost o Vyškově z let 1131-1141 zmiňuje pouze příslušnost jednoho tamějšího aratra $\mathrm{k}$ pozemkové výbavě kostela sv. Václava v Olomouci. Jinak lokalita byla knížecím majetkem a zvolna nabývala na významu. Comes Jakub z Vyškova mezi svědky na listině z roku 1201 svědčí o existenci vysokého zeměpanského činitele (CDB I, č. 115; CDB II, č. 22). Protože tak bývají označováni správci hradských provincií, vynořila se domněnka, že byl něco jako „kastelán“ místního regionálního centra - hradu. Ovšem jiný hrad než Pustiměř - Zelená Hora se v blízkosti nevyskytoval a hlavně se nenacházel ani na nizoučké ploché terase nad soutokem Drnovky, Rostěnického potoka a říčky Hané, na níž se rozkládalo sídliště jménem Vyškov. Jako sídlo správy postačoval prostý, zřejmě dřevěný a jen lehce hrazený dvorec, ale neznáme žel ani jeho polohu. Nijak nepomohla ani archeologie, vždyt' nečetné výzkumy v centru a v bezprostředním okolí města neposkytly stř̌edověký materiál starší 13. století. A navíc bez zvláštní koncentrace svědčící o existenci exponovaného objektu. Frekvence nálezů z doby od poloviny 13. do 14. století naprosto převažuje (Doležel 1995, 205; Baarová 2003; 2006; Mikulková 2008; Rybářová 2013).

Rozpor v nálezech a písemném doložení místa před polovinou 12. století lze řešit hledáním starší osady jinde. Protože dřívější trasa stezky Vyškovskou bránou patrně vedla sušším terénem - úpatím svahů Drahanské vrchoviny, lze předpokládat, že trojúhelné tržiště na novější vidlici cest se formovalo až po roce 1200. Starší ulicovou vsí mohly být Brňany (dnes ulice V Brňanech), kde v místě kaple sv. Michala stával do roku 1806 původně farní kostel a u něho do roku 1789 hřbitov. Pokud je kaple pozůstatkem obdélného kněžiště, nelze vyloučit vznik kostela již v pozdně románském období. Brňany na mírně stoupajícím terénu nikdy neohrozily povodně a mezi nimi a Vyškovem se již v roce 1277 na Rostěnickém potoce rozléval rybník (Nekuda 1965, 311; CDB V/2, č. 845). Týž rybník se vzpomíná roku 1403 a ves roku 1267 v závěti biskupa Bruna ze Schauenburka, kde však Vyškov již figuruje jako městečko (Lechner 1902/1, 20; CDB V/2, č. 526). Méně pravděpodobná je úvaha, že starší vsí byla dnes slepá Štefánikova ulice (Kuča 2011, 505) s bývalým špitálem (proto dřive Špitálka, ale též Trávník). 


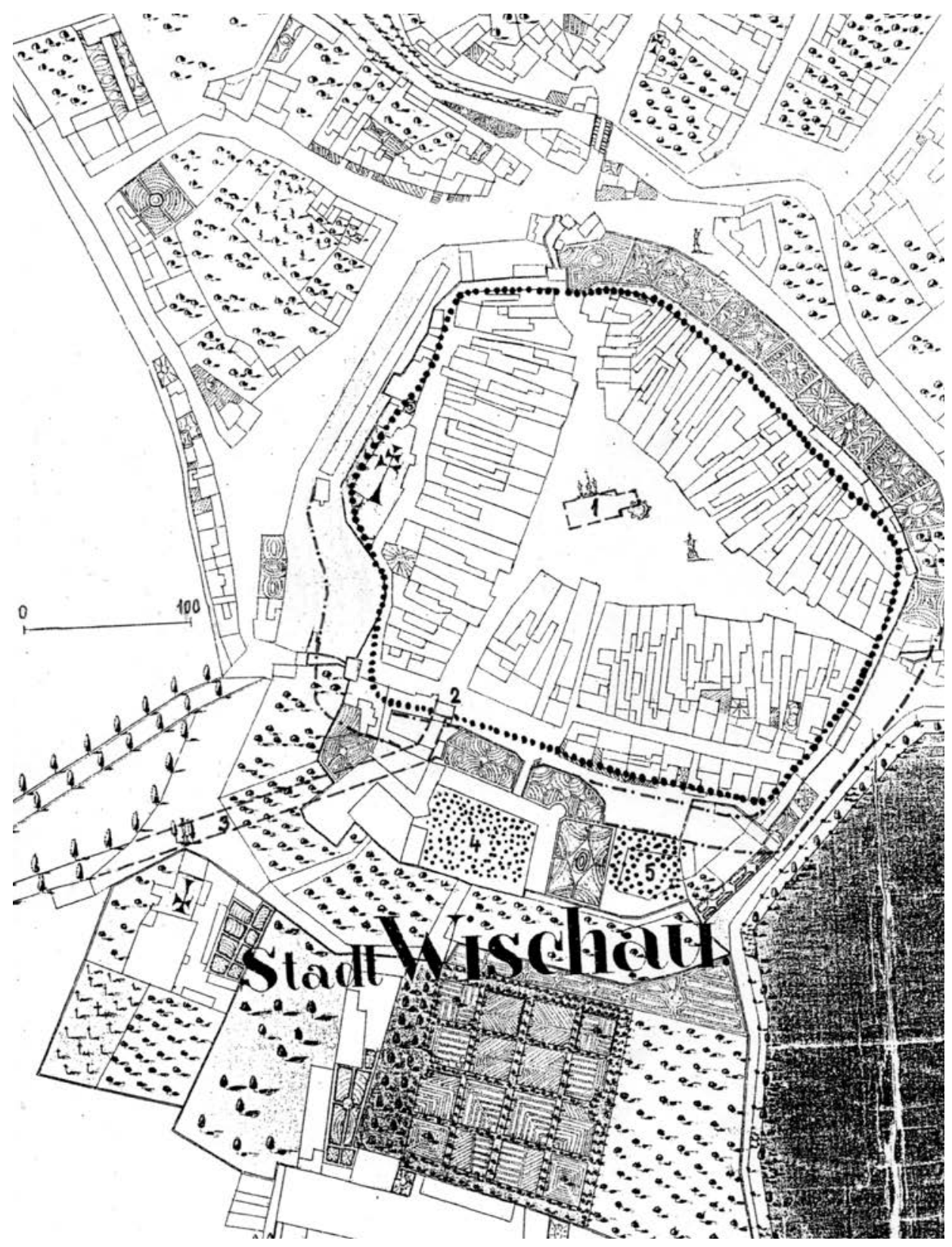

Obr. 1. Předpokládaný rozvrh původního jádra Vyškova zhruba do roku 1440. Tečkovaná linie ohraničuje toto jádro možnou linii ohrazení, čerchované čáry vyznačují část možných starších př́íkopů využitých později pro hrad; 1 - pravděpodobné místo staršího kostela na tržišti, 2 - předpokládaná Brněnská brána před stavbou hradeb, 3 - původní trasa cesty od Brna (čárkovaně), 4, 5 - možné varianty situování dvorce zeměpanského (pak biskupského) provinčního správce. Do podkladu indikační skici z roku 1826 zakreslil M. Plaček.

Abb. 1. Vermutliche Gliederung des ursprünglichen Kerns von Vyškov ungefähr bis zum Jahr 1440. Die gepunktete Linie umgrenzt diesen Kern - mögliche Einfriedungslinie, die strichgepunktete Kennzeichnung stellt einen Teil möglicher und später für die Burg genutzten älteren Gräben dar; 1 - wahrscheinlicher Standort der älteren Kirche auf dem Marktplatz, 2 - vermutliches Brünner Tor vor dem Bau der Stadtmauer, 3 - ursprüngliche Trasse des Wegs nach Brünn (gestrichelt), 4, 5 - mögliche Standortvarianten des landesherrschaftlichen (dann bischöflichen) Herrenhofs des Provinzverwalters. Die Indikationsskizze aus dem Jahr 1826 wurde von M. Plaček in die Vorlage eingezeichnet. 


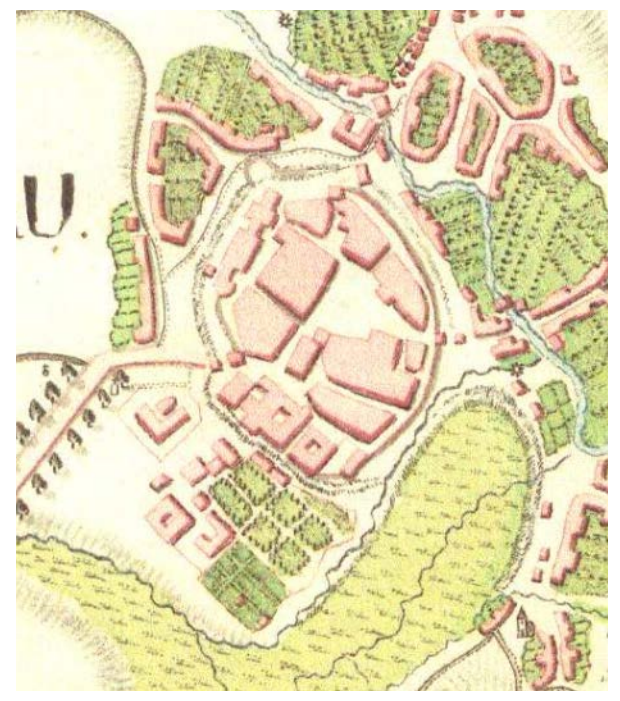

Obr. 2. Aglomeraci osídlení zachytila sekce č. 66 mapy 1. vojenského mapování z let 1764-1768. Kromě města a zámku v hradbách je na jihu zámecká zahrada a dvůr, na východě Křečkovice, na jihovýchodě Brňany s kostelem sv. Michala.

Abb. 2. Siedlungsagglomeration dargestellt in Sektion Nr. 66 der Karte der 1. militärischen Kartierung aus den Jahren 1764-1768. Außer Stadt und Schloss innerhalb der Stadtmauer befindet sich im Süden Schlosspark und Hof, im Osten Křečkovice, im Südosten Bründlitz (Brňany) mit der Kirche St. Michael. 1413 probíhala protihusitská synoda. Možná jím mohl být týž biskupský dvůr, který ležel přímo před městem a před rokem 1394 vyhořel (CDB V/2, č. 509; CDB V/3, č. 1437; Krafl 2000, 69; Mlateček 2009, 314). Nepochybná je jeho dočasná obnova, nejméně do vypálení Vyškova husity v roce 1423, přičemž nelze vyloučit, že byl situován v prostoru dnešního pivovaru. S městem, poprvé zmíněným v roce 1367 (civitas), ho téměř jistě nespojovaly hradby a ani branská věž v hradbě na městské pečeti z roku 1403 zděné opevnění města nedokládá (CDM X, č. 4; Mlateček 2009, 311). Formulaci ante civitatem k roku 1321 sice uvádí Karl Lechner (1902/I, 6), ovšem i tak lze předpokládat, že zástavbu omezenou pouze na bloky kolem tržiště v poslední třetině 14. století, či nejpozději před vzplanutím husitských bouří obehnalo jednoduché dřevěné hrazení $\mathrm{s}$ př́ikopem. Místo pracné palisády spíše šlo o lepší plaňkový plot, či stěnu z břeven v drážkách sloupů. Stopy ani takového opevnění neznáme, ale zřejmě existovalo, nebot' při obnově práv biskup Tas z Boskovic (1459-1482) chválil měšt’any za úpornou obranu před husity v roce 1423. I tak však bylo město zničeno a v roce 1448 biskup Pavel z Miličína údajně žádal kapitulu, aby mohl prodejem zboží získat finance na stavbu hradeb, jež měly poskytnout ochranu obyvatelům obnoveného města (Mlateček 2009, 321; Nekuda 1965, 293 - cit. archivní výpisky Vojtěcha Procházky). K obnově nedošlo hned, vždyt' z husity obsazeného hradu Melice zhruba dva roky hrozilo širokému okolí nebezpečí. Vypudit jejich posádku se podařilo energickému markraběti a vévodovi rakouskému Albrechtovi a k poničenému Vyškovu a pustiměřskému klášteru (1426) se tak připojil pobořený melický hrad (Zháněl 1967, 10-11). Správa lenního obvodu se tak z Melic musela přenést jinam, evidentně do ekonomického centra - města Vyškova.

Zápis z roku 1449 spolehlivě dokládá, že tehdy se již udělovala léna ,v nové tvrzi při předni bráně města“ (bezpochyby Brněnské). V roce 1465, kdy existovala i brána Olomoucká, jsou zmíněny hrad (tvrz) a nově budované hradby (Lechner 1902/I, 104, 120). Leč přídavné jméno „nový“ neznamená obnovu dřivější (a zničené) stavby, ale opravdu stavěné od základu. Zhruba 


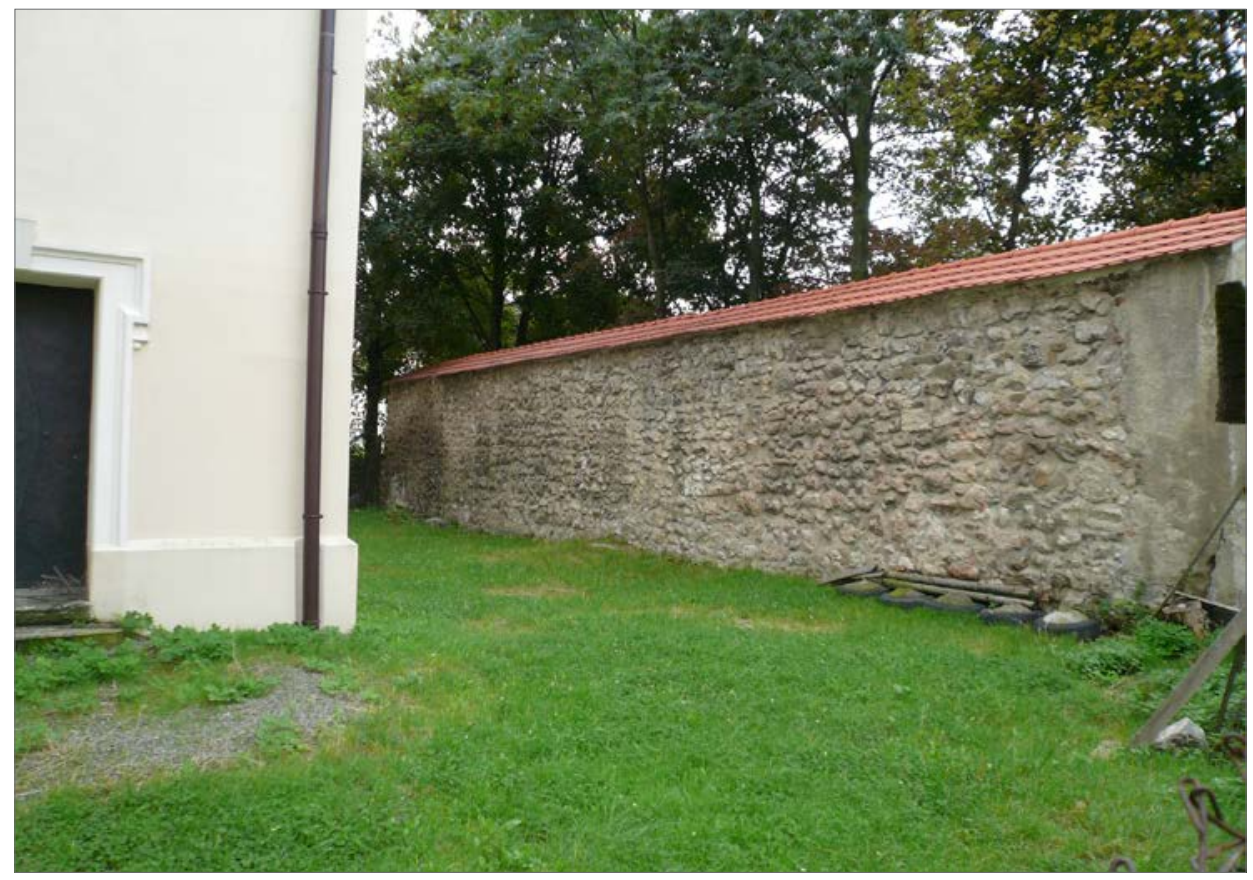

Obr. 3. Snížená městská hradba za děkanským kostelem. Foto M. Plaček.

Abb. 3. Tiefer gelegte Stadtmauer hinter der Dechanatskirche. Foto M. Plaček.

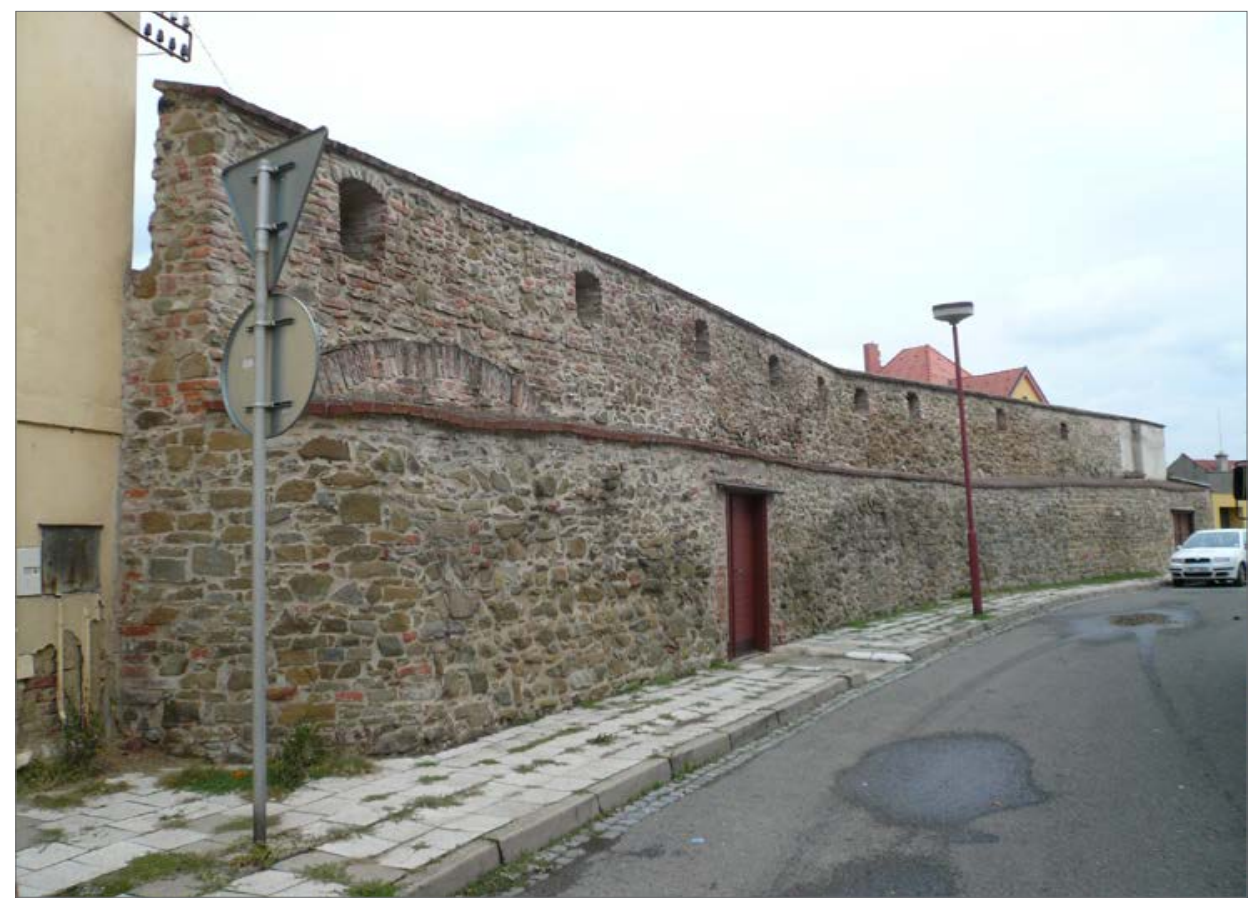

Obr. 4. Hradba v Pivovarské ulici na severovýchodě města. Foto M. Plaček.

Abb. 4. Stadtmauer in der Bierbrauereistr. im Nordosten der Stadt. Foto M. Plaček. 


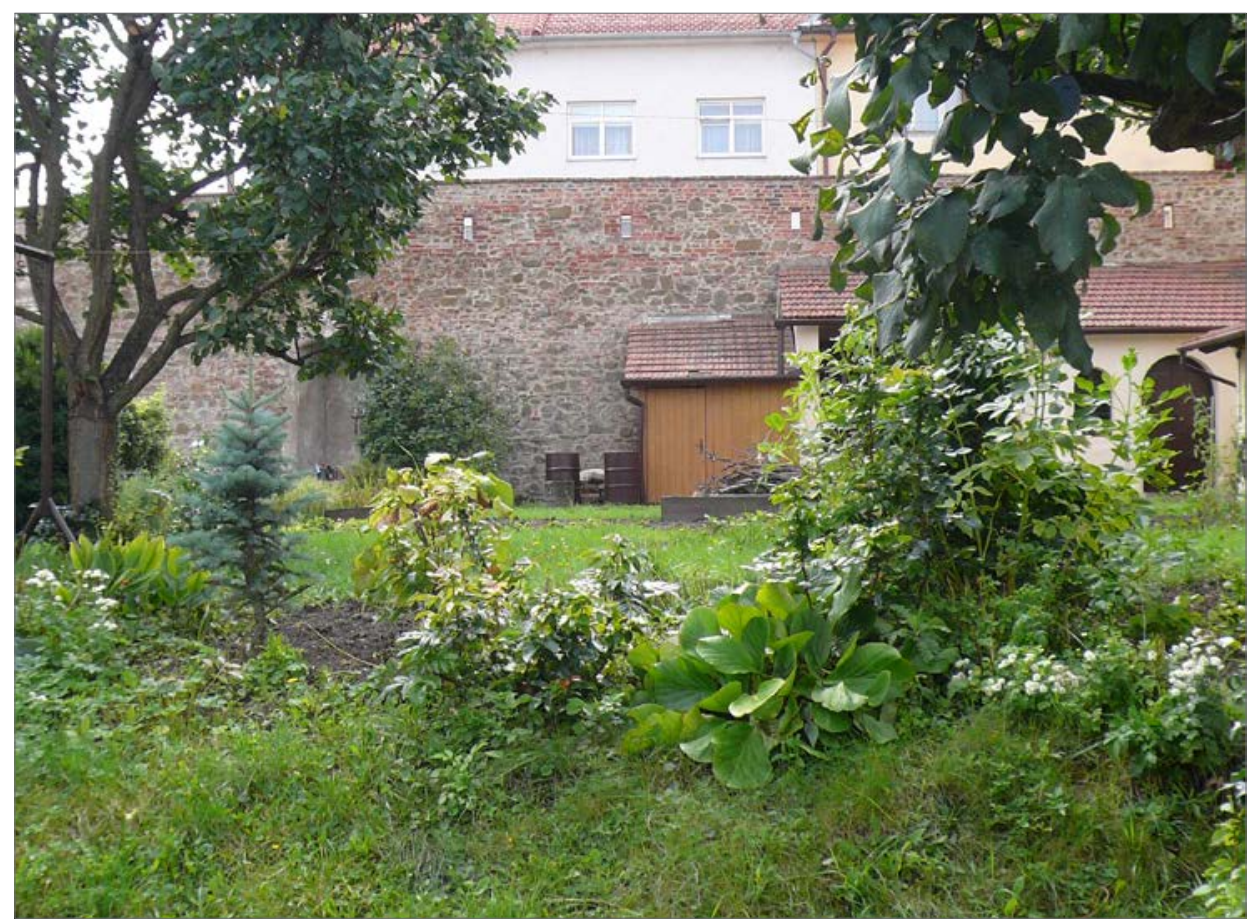

Obr. 5. Hradba na severovýchodě města zvenčí. Foto M. Plaček.

Abb. 5. Stadtmauer im Nordosten der Stadt von außen. Foto M. Plaček.

z poloviny 15. století také pocházejí dochované části prvních kamenných měštanských domů při rynku (Eliáš 2004 - shrnul poznatky svých SHP uložených na MěÚ ve Vyškově) a koncem druhé třetiny 15 . století započala stavba nového děkanského kostela Nanebevzetí Panny Marie. K založení došlo za severozápadním blokem náměstí v místě dvou židovských domků (Nekuda 1965, 294), tedy ve stísněném prostoru, a biskup Tas proto nehleděl na orientaci, a tak osa chrámu směřuje víc k severu než k východu. Historici umění Pavel Borský a Dagmar Černoušková $(2001,123)$ datovali fundaci hlavně nutností náhrady zničeného kostela na rynku při dalším dobytí města. Přitom zvolili rok 1464 z údaje, že právě tehdy byl za války krále Jiřího s Matyášem Korvínem Vyškov vypálen (Nekuda 1965, 294).

Konflikt však vypukl až na jaře 1468 a k opakované devastaci města zřejmě došlo koncem roku 1469 při tažení Jiřího syna knížete Jindřicha k zásobení obleženého Uherského Hradiště. Hejtmanem útočného oddílu měl být hejtman Mikuláš Střela, jenž se tehdy pokusil i o Brno (Frankenberger 1960, 67, 110; Krones 1900, 86 - vychází z Tomáše Pešiny). Vzhledem k započetí stavby trojlodního chrámu v roce 1470 a pozoruhodné velikosti není překvapením její vysvěcení až roku 1496 (Borský-Černoušková 2001, 123, 122; Lechner 1902/I, 120). Volných ploch kolem nového kostela bylo pomálu, vždyt' jen několik metrů podél něho běžela hradba, a k pohřbívání bylo málo místa. Proto nepřekvapují pohřby měštanů v Brňanech (Borský-Černoušková 2001, 123).

Je-li centrem města plocha obehnaná hradbami, patří k ní krom bloků kolem tržiště ulice Kostelní, Nádražní, Dobrovského, náměstí Čsl. armády a Zámecká ulička. Ta se kupodivu nachází na opačném konci jižní části města než zámek a byla k jádru města připojena až při obnově po husitském zničení. Se stejnou ironií zní název Pivovarské ulice, která se táhne na protilehlé straně města s pivovarem. Vzhledem k sevření areálu města tokem Hané, již zmíněným rybníkem a sice krátkým, nicméně strmým svahem na západě se předměstí zformovala až v 19. století. Výjimkou při cestě na Olomouc byl tzv. Trávník (později Štefánikova ul.), v němž také 


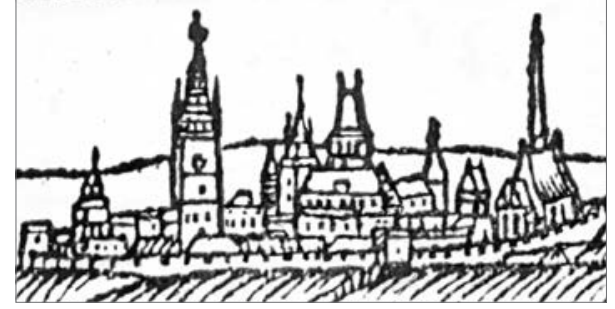

Obr. 6. Pohled na město od severu, dřevořez Jana Willenbergera z roku 1593. Podle Paprocký 1993, str. za fol. 375. Abb. 6. Blick auf die Stadt von Norden, Holzschnitt von Jan Willenberger aus dem Jahr 1593. Nach Paprocký 1993 , S. hinter Fol. 375. vystavěli špitál s kostelíkem sv. Anny a též posloužil jako krystalizační jádro severovýchodního předměstí. S městem na východě sousedící Křečkovice a již zmíněné Brňany představovaly silnicové vesnice, které tvořily samostatná léna. S městem se spojily až roku 1942 a předměstí na severozápadě ve směru na Dědice rostlo teprve od počátku 18. století (srov. Kuča 2011, 496-497).

Město vymezoval a chránil pás opevnění. Než vystavěli kamenné hradby, s jejichž počátkem je spojeno jméno biskupa Pavla z Miličína (1434-1450), starší zástavbu asi obepínaly dřevěná ohrada a př́íkop před ní. Jelikož k jádru města byla pravděpodobně dodatečně připojena jihozápadní úseč městského areálu, byl příkop před zámkem asi zbytkem toho staršího. Nemůžeme ani vyloučit, že součástí tohoto prvotního hrazení nebyly už zděné branské věže. Na schematickém plánu právovárečných domů z roku 1617 u nápisu Brünnerthor přehrazuje ulici lehce obdélná budova a krom toho na plánu města ze sbírky F. F. v. Nicolaie se před východním koncem úzkého a napříč stojícího domovního bloku musí ulice $\mathrm{k}$ Brněnské bráně v hradbách zalomit v pravém úhlu (SOkA Vyškov ve Slavkově u Brna, AMV I, kart. 477, i. č. 869; Württembergische Landesbibliothek Stuttgart, Sammlung Nicolai, Bd. 146, Fol. 18). Pomocný argument též představuje věžovitá budova stojící v místě zlomu trasy na vedutě města ze sbírky Hofferian z třetiny 18. století (AMB, sbírka D. J. I. Hoffera, sign. 39/122).

Plocha, kterou uzavíraly hradby včetně zámku (hradu), je 9,0 ha, město s minimálně vyvinutou uliční sítí tudíž patřilo k menším urbánním útvarům. Hradby ho organicky a měkce obepínaly a s výjimkou mírně vystupující (dodatečné) části západního křídla zámku vybočuje hradební zed’ pouze na severozápadě, a přirozeně tak vytváří plochu, do níž vměstnali novostavbu farního kostela. Hradby z pečlivě rovnaného kamene se dílem uchovaly právě podél kostela (tam snížené) a v obvyklé výšce (5-6 m) a délce přibližně 90 m v Pivovarské ulici. Hradební zed' tvoří její severovýchodní stranu, a proto jde o typickou hradební uličku umožňující přístup a rychlý přesun obránců. Hradební zed' je (stejně jako u kostela) 1,55-1,6 m silná a i po památkové úpravě je koruna dosud opatřena ústupkem v místě ochozu a vysokým parapetem prolomeným stř́lnami. Žel jistá část vznikla při novodobých úpravách. Zmíněný úsek za kostelem je podstatně snížený odbouráním ochozu. Brána se nedochovala ani jedna, protože již v 19. století byly obtížnou překážkou houstnoucí dopravní frekvence. Roku 1834 zbořili s velkou částí hradeb bránu Olomouckou a Brněnskou a v roce 1843 došlo i na bránu Kroměřížskou (Nekuda 1965, 299).

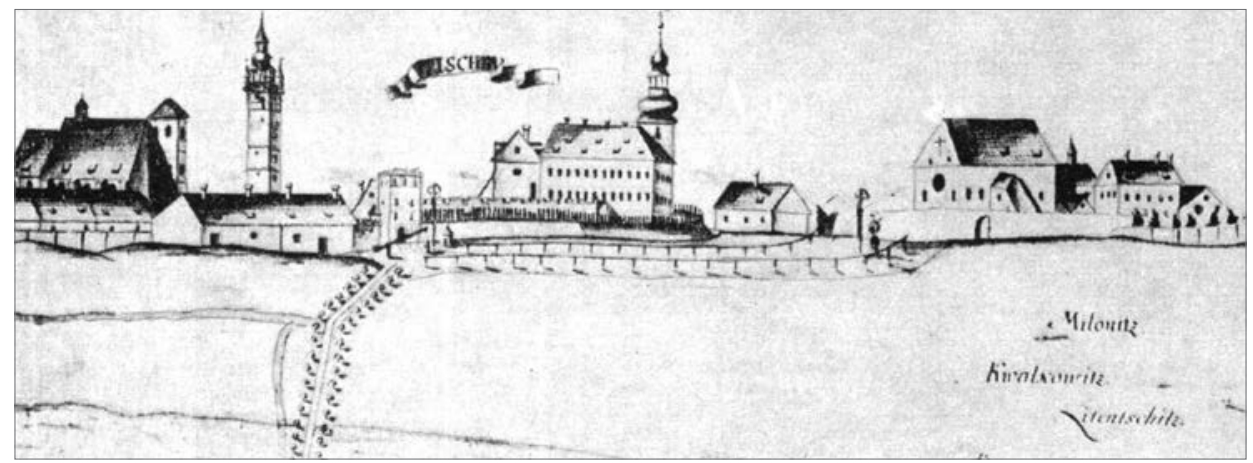

Obr. 7. Město a zámek od západu v roce 1736. Podle Burian 1975, obr. 14.

Abb. 7. Stadt und Schloss von Westen im Jahr 1736. Nach Burian 1975, Abb. 14. 
Díky řadě historických vyobrazení a novověkých plánů přesto máme poměrně slušné povědomí o jejich základní podobě. Všechny byly dvoupatrovými hranolovými věžemi s průjezdy a vždy jen jediným portálem vjezdu, postrádaly tedy branky pro pěší. Z mapy stabilního katastru vyplývají přibližné půdorysné rozměry věží. Brněnská stála na podstavě $12,5 \times 8,5 \mathrm{~m}$, Olomoucká $11 \times 7 \mathrm{~m}$ a nejmenší Kroměřížská měla rozměry 7,5 $\times 9 \mathrm{~m}$ a jak se zdá, všechny byly vybaveny svoditými mosty. Brány dodatečně, ale s ohledem na pozdní vznik hradebního prstence jen s nevelkým časovým odstupem doplnili předbraními. Brány Brněnská i Kroměřížská na východě evidentně obdržely druhé a nižší hranaté věže před př́íkopem, které s branskými věžemi v hradbě propojovaly zděné koridory spočívající zčásti na mostech. Olomouckou bránu opatřili prvkem, který se blížil barbakánu, a jeho vnější branská věž stála vzorově mimo osu hlavní věže. Proto trasa cesty předbraním zahnula a do předpolí vystoupila bokem.

Kromě branských věží se v hradbách města nevyskytovaly žádné jiné věže, pokud nepočítáme pozdní zvonici u kostela, a obráncům nejprve sloužily jenom hradební ochozy. Původně nebyly kryté a ukončovalo je cimbuří zřetelně patrné na dřevořezu vedutisty a ilustrátora díla Bartoloměje Paprockého z Glogol z roku 1593. Vyškov zobrazuje od severu a přes val jsou viditelné všechny tři věže bran, u Kroměřížské dokonce i vnější věž, ale také ostatní hlavní budovy města - hrad, děkanský kostel a vysoká radniční věž. Pozoruhodný je průkop okružního náspu pro cestu z Olomoucké brány (Paprocký 1993, str. za fol. 375). Hradba spojující věž Brněnské brány se zámkem ještě v roce 1736 vrcholila cimbuřím, avšak roku 1728 jsou na vedutě ze souboru D. J. I. Hoffera všechny viditelné úseky hradeb opatřeny stř́šsou ochozů. Vedle pivovaru na jihu napolo vystupoval z hradeb dům palácového charakteru, jehož patro se otevíralo velkými okny galerie, podle legendy obrazu dům knížete-biskupa zvaný Puglietta (Burian 1975, obr. 14; AMB, sbírka D. J. I. Hoffera, sign. 39/122). K zámku (hradu) v jihozápadním koutu města se hradby připojily ihned v průběhu jejich stavby.

Celý obvod hradeb nejprve lemoval příkop a val nasypaný z vytěžené zeminy. Prvotní forma přirozeně nepostačovala a ještě nějakou dobu před rokem 1590 zesílili všechny tři brány předbraními. $Z$ analýzy a porovnání vedut zřejmě jenom barbakán připomínající předbraní Olomoucké brány následovalo až po tomto roce, avšak pravděpodobně brzy. Druhý okruh opevnění v podobě zděné parkánové hradby předpokládala Zdena Jeřábková $(1999,250)$, leč o parkánu nelze hovořit ani na reliéfně nejpř́ihodnější východní straně. I tak byl druhý pás fortifikace alespoň plánován a patrně zčásti realizován, jenže v jiné podobě a až v novověku. Na situačních plánech

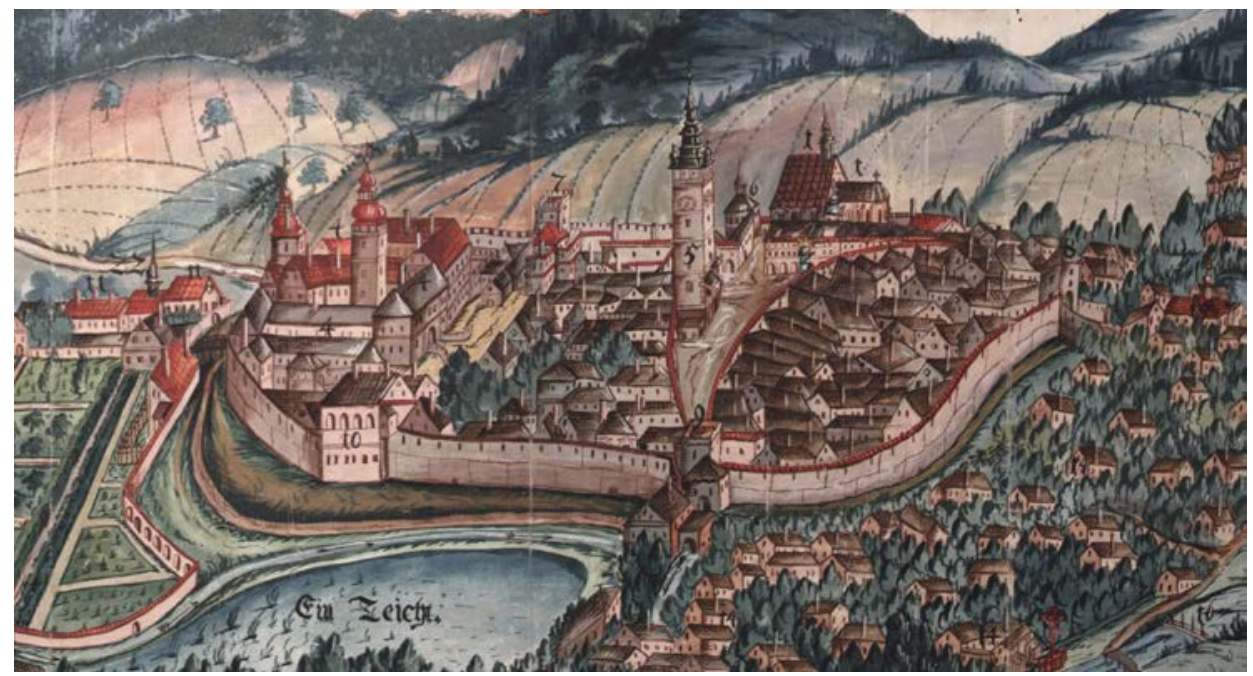

Obr. 8. Veduta města od východu z roku 1728. Zdroj AMB, sbírka D. J. I. Hoffera, sign. 39/122.

Abb. 8. Stadtansicht von Osten aus dem Jahr 1728. Quelle Archiv der Stadt Brno, Sammlung D. J. I. Hoffer, Sign. $39 / 122$. 


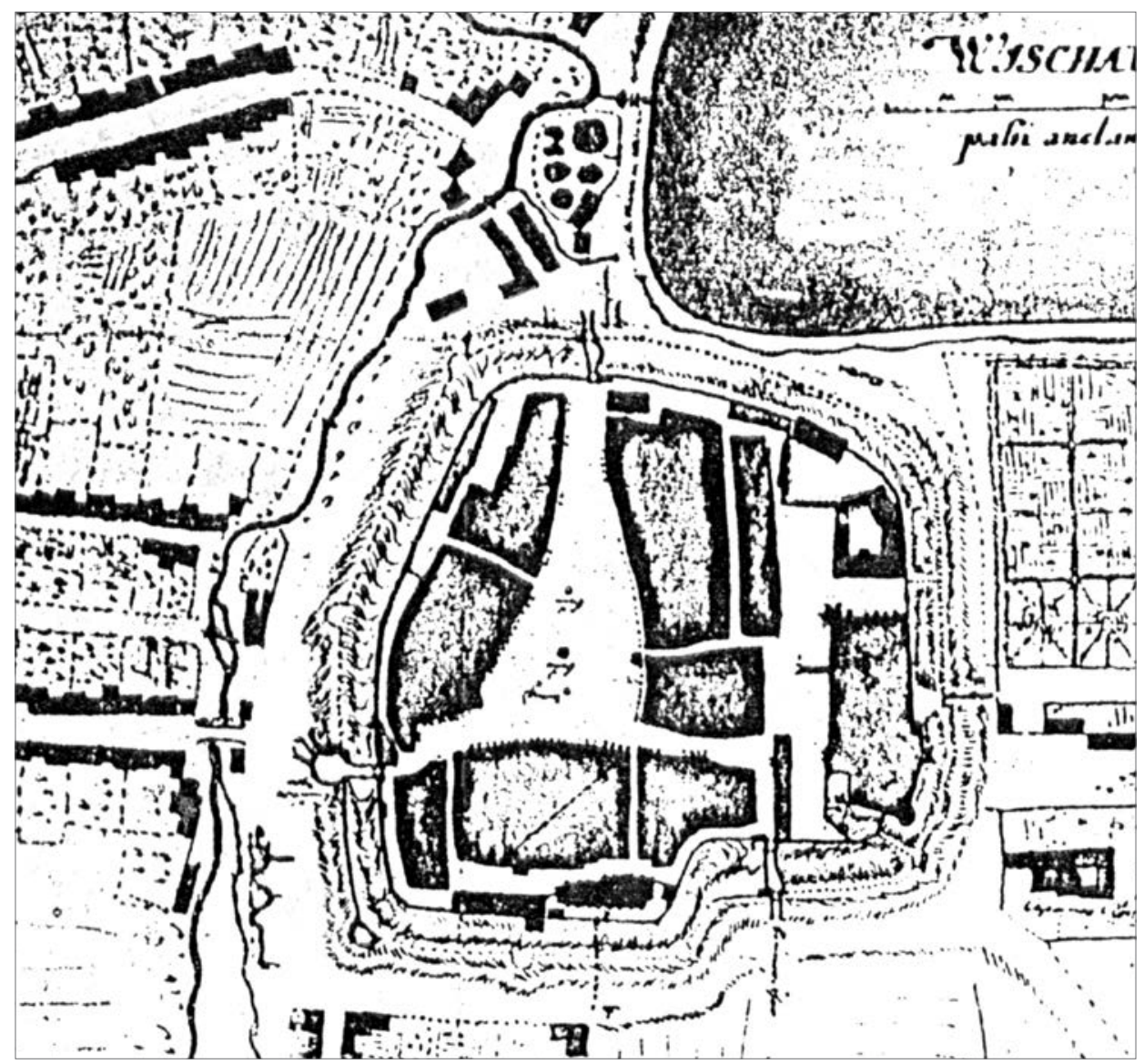

Obr. 9. Situační plán Vyškova s opevněním z let 1710-1720. Zdroj Württembergische Landesbibliothek Stuttgart, Sammlung Nicolai, Bd. 146, Fol. 18.

Abb. 9. Lageplan von Vyškov mit Befestigung aus den Jahren 1710-1720. Quelle Württembergische Landesbibliothek Stuttgart, Sammlung Nicolai, Bd. 146, Fol. 18.

Vyškova z doby kolem roku 1720 se jeho půdorysný tvar čárkovaně rýsuje na východě, severu a jihozápadě. Využil však korunu náspu před př́íkopem, ovšem kromě jihovýchodu a severovýchodu, kde město nejprve chránil rybník a podél něho tekoucí Drnovka, a poté říčka Haná. Jinde před ním vyhloubili druhý př́ikop. Přibližně současně s barbakánem Olomoucké brány obdrželo severní nároží městských hradeb masivní zděný rondel podkovovitého tvaru o průměru ca 17-18 m, který s barbakánem spojovala hradba. Vzhled rondelu dokonale zachytil anonymní malíř na votivním obrazu $\mathrm{v}$ Křtinách vytvořeném $\mathrm{v}$ souvislosti s velkým požárem města $\mathrm{v}$ roce 1753 a je pečlivě zakreslen do plánu revize vyškovského opevnění z roku 1778. Inspekci kvůli počínající válce o bavorské dědictví nařídil císařský kancléř a přinesla pozoruhodné a často tristní informace o stavu opevnění řady moravských měst. Zpráva inspektora byla žalostná. Rondel byl polozřícený, hradby místy pobořené a značná část př́kopů zasypaná či zanesená (Smutný 2009, 216, 222).

Proti kvalitě z doby kolem roku 1720 se projevila výrazná degradace a třeba př́kop zůstal jen na východě a u zámku. Dř́ive na valu nasypali a zhutněním zpevnili linii fortifikace vybavenou vystupujícími prvky, které umožnily boční palbu. Detailní situace jižní úseče města se zámkem, dvorem (pivovarem) a biskupským palácovým domem (pak úřednickou budovou) dokládá, že jádro zámku zvenčí chránila sypaná, asi dřevem plentovaná hradba se dvěma drobnými bastionky. 


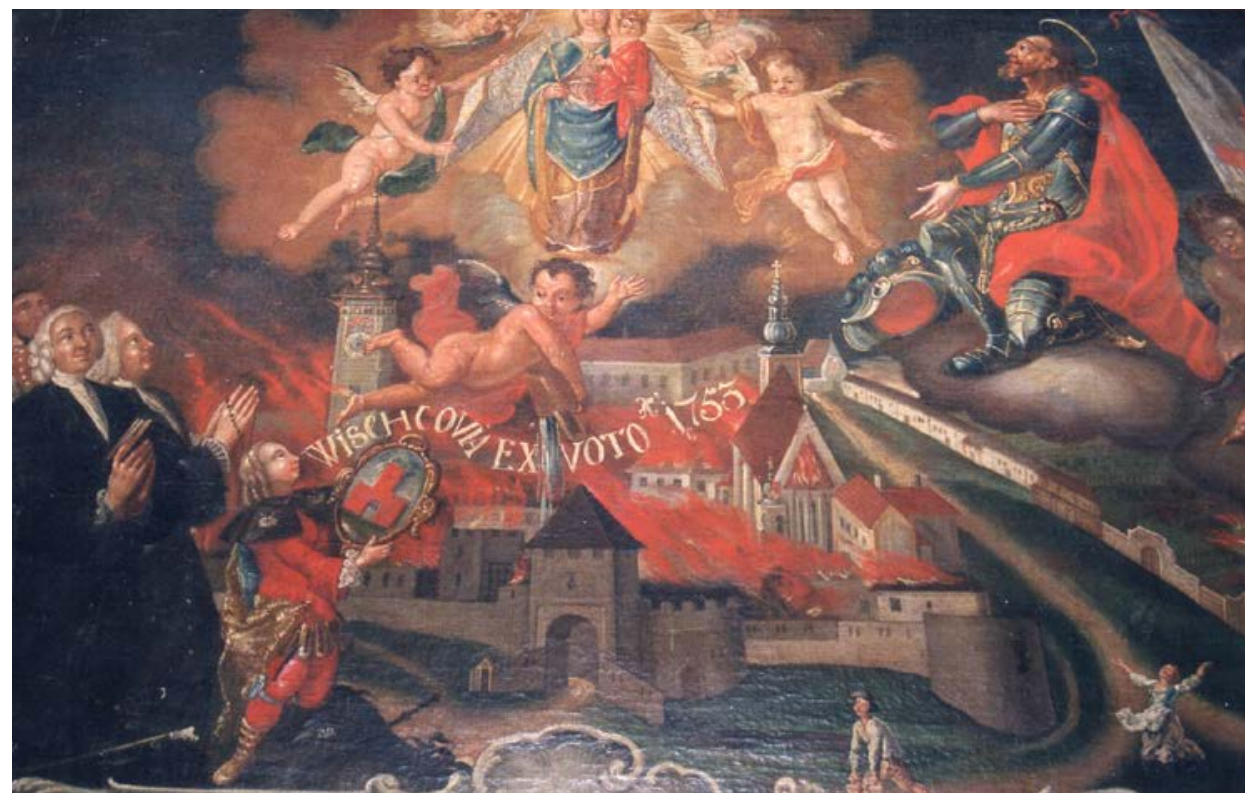

Obr. 10. Severozápadní kout města s nárožním rondelem na votivním obrazu k požáru v roce 1753 v poutním kostele v Křtinách. Foto archiv M. Plačka.

Abb. 10. Nordwestliche Ecke der Stadt mit Eckrondell auf einem sich in der Wallfahrtskirche von Křtiny befindenden Votivbild zum Brand von 1753. Foto Archive von M. Plaček.

Od zámku až ke Kroměřížské bráně a na opačnou stranu k rondelu se po starším valu patrně táhla palisádová stěna. Mezi Olomouckou a Kroměřížskou branou z palisády vystupovaly dvě oblé bašty (WLbS, Sammlung Nicolai, Bd. 146, Fol. 18). Tento druhý prstenec do značné míry potvrzuje i málo známý plánek vyškovské fortifikace z vídeňského Kriegsarchivu datovaný rokem 1749. Jeho tvůrcem je Charles de Lorraine (nebo Le Roy?) a je s ním spojena perokresba veduty Vyškova od západu. Východní segment opevnění běžícího po koruně valu je vybaven třemi trojúhelnými redany, u zámku pak redanem a dvojitým redanem zvaným biret (Lorraine 1749, nestr.). Navíc Charles před Brněnskou branou místo předbraní nakreslil nevelký ravelín. ${ }^{1}$

Mezi oběma zmíněnými plány jsou viditelné drobné odlišnosti spočívající nejen v různém vidění a pečlivosti autorů, ale asi i ve vývojovém posunu. Odstup skoro třiceti let mohl znamenat zkvalitnění započatého vnějšího okruhu, patrně s narušením klidných poměrů ihned po nástupu Marie Terezie na trůn (1740). Spory o habsburské dědictví bleskově přerostly ve válečné konflikty se sousedními mocnostmi (Bavory, Sasko, Prusko) a s Francií, což vyvolalo zesilování fortifikací nejen větších měst, ale i komunikačních uzlů. Zřejmě proto došlo i k jisté modernizaci opevnění biskupského Vyškova, ale po ustálení středoevropské státní struktury a rychlé ztrátě Slezska se situace zklidnila. Zároveň pokrok válečné techniky a vojenství dále znehodnocoval stárnoucí a chátrající opevnění nevelkých měst a strategická obrana se přesunula na zemské pevnosti. Zjištění výše zmíněné inspekce (ve Vyškově 1778) byla natolik závažná, že započala stavba Terezína, Josefova a zpevňovaly se fortifikace Olomouce a Brna. Údržba běžných hradeb upadala, a když pozvolna začaly překážet dopravě a rozvoji, zejména $\mathrm{v}$ počátcích průmyslové revoluce, probíhala jejich urychlená likvidace.

Ve stručnosti se dotkneme souboru zámku, s nímž sousedily dvůr (později pivovar) a palácová (pak úřední, dnes zaniklá) budova, které tvoří vrchnostenský sektor historického jádra města. Již jsme konstatovali, že jde o areál, jenž nepatřil k nejstaršímu osídlení a s městem byl

1 Od téhož autora a ze stejného zdroje pochází kresba zámku Miroslavi, kterou publikoval Bohumil Samek $(1999,522)$ a kreslíře označil jako Ch. Le Roy. 

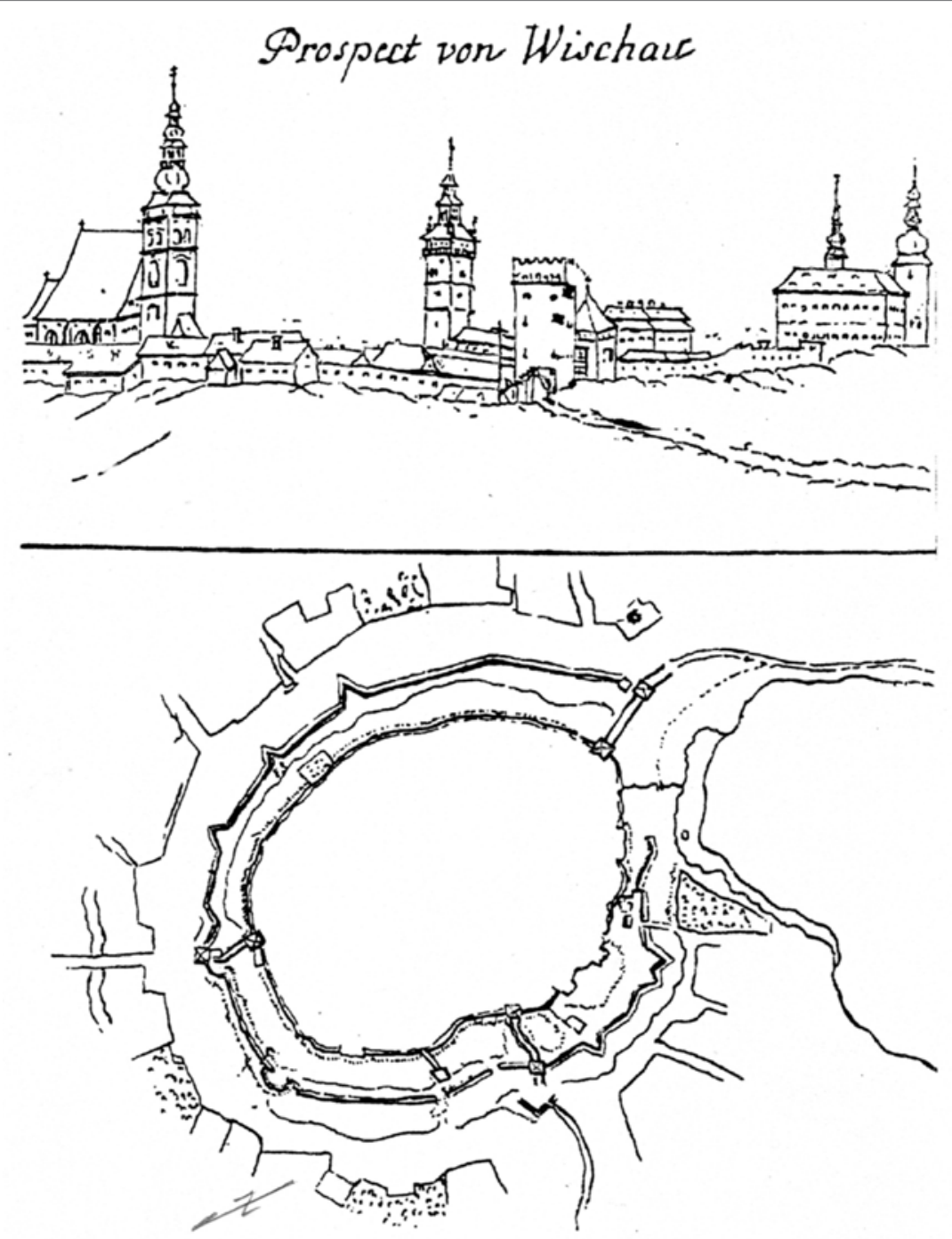

Obr. 11. Poněkud deformovaný plán zobrazuje fortifikaci Vyškova s druhým pásem opevnění na starším náspu a pohled na město před polovinou 18. století od Charlese de Lorraine. Podle Lorraine 1749 nestr.

Abb. 11. Leicht verzerrte Planskizze der Befestigung von Vyškov mit zweitem Befestigungsstreifen auf der älteren Aufschüttung und Blick auf die Stadt vor Mitte 18. Jhdt. von Charles de Lorraine. Nach Lorraine 1749 unpaginiert.

spojen až s obnovou po totální devastaci za husitských válek. Ale nelze se podivovat tomu, že zničení Vyškova husity v roce 1423 bylo tak radikální. Tehdejší biskup Jan Železný (1416-1430) byl jejich úhlavním nepř́itelem a útok na Vyškov byl odvetou za dobytí hradu Račic z rukou př́vrženců kalicha rok předtím. Písemné zprávy vypovídají, že vyškovský hrad byl v roce 1449 schopen sloužit realizaci správní agendy. Zápis udílených lén proběhl v horní jizbě (stuba superiori), tedy muselo již stát patro včetně střechy. Přitom skoro jistě v roce skonu císaře Zikmunda (1437) stavba sotva započala, nebot' Vyškov, patrně jeho díly, se udělovaly lénem (srov. Mezník 1999, 425, 424; Lechner 1902/I, 104; 1902/II, 321).

Termín tvrz (lat. municio) středověcí písaři často používali pro sídla v rovinách bez ohledu na jejich velikost. Zároveň lze předpokládat, že toto sídlo již bylo hradbou spojeno s existující věží 


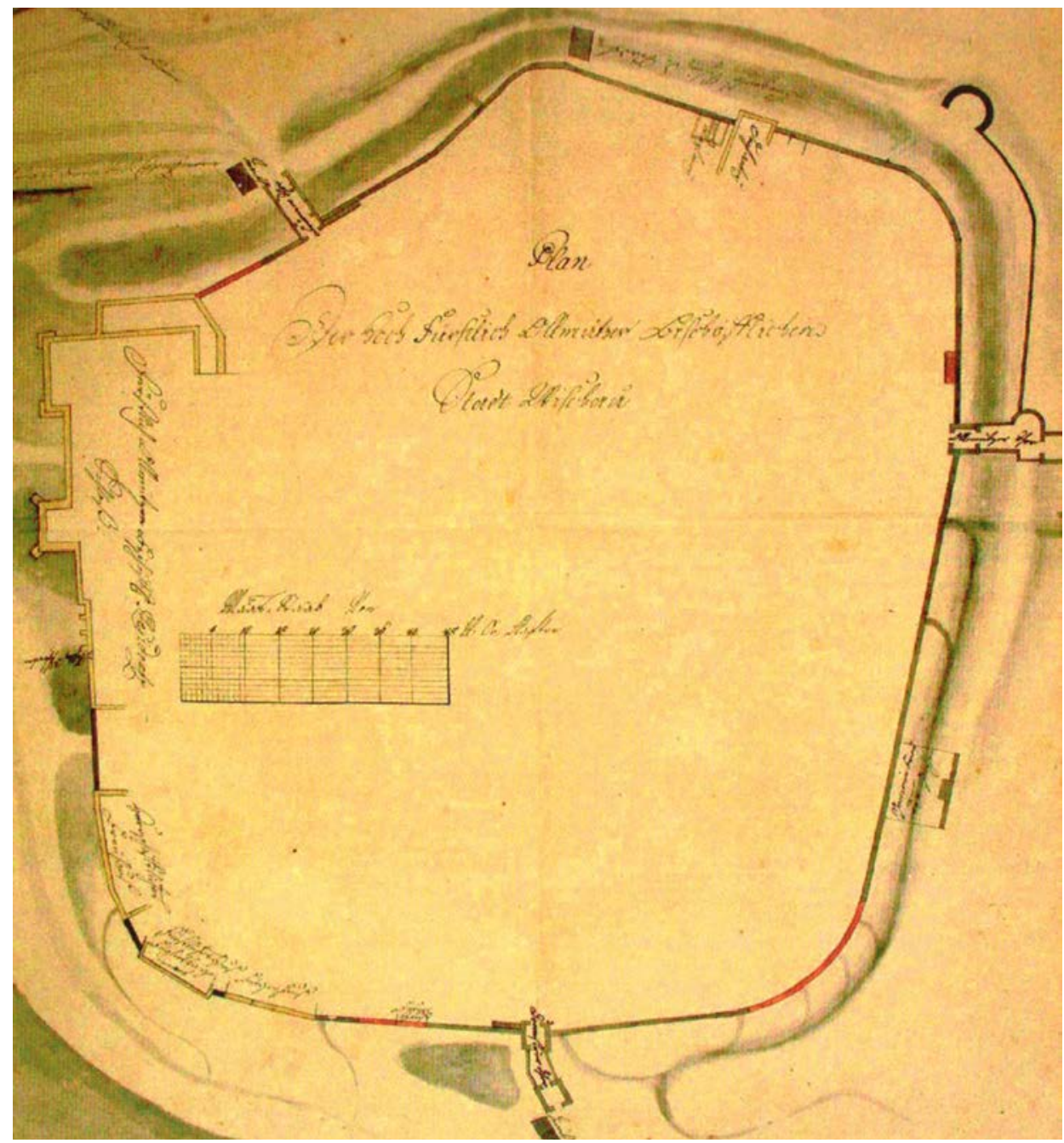

Obr. 12. Plán revize opevnění Vyškova z inspekce stavovské komise z roku 1778. Podle Smutný 2009, obr. 8.

Abb. 12. Revisionsplan der Befestigung von Vyškov von einer Inspektion der Ständekommission aus dem Jahr 1778. Nach Smutný 2009, Abb. 8.

Brněnské brány. Urychlení stavby hradu, jakož obnovy a opevňování města, vyvolala mimo jiné skutečnost, že biskupskou sídelní Kroměříž v roce 1432 obsadili husitsky orientovaní rytíŕi a válečníci bratři z Moravan. Pocházeli z rozrodu Vítkovců - měli ve znaku pětilistou růži - a brzy po zbohatnutí se na původ rozpomněli a začali se psát z Landštejna. Po Lipanech od Zikmunda Lucemburského přesto obdrželi zástavní právo na město i tamní hrad a ty s kratšími přestávkami v zástavě zůstaly až do roku 1500, i když se držitelé později střídali (Peřinka 1911, 173-179).

Hrad ve Vyškově tudíž biskupům sloužil tak trochu jako náhrada za Kroměříž, ale snad i proto mu věnovali odpovídající pozornost, zvláště Pavel z Miličína a Tas (Protasius) Černohorský z Boskovic. Původně pozdně gotické opevněné sídlo mělo dvojdílnou dispozici - starší lichoběžné jádro $(65 \times 43 \mathrm{~m})$ a obdélné, renesančně přestavěné předhradí. Jádro sídla nazývali až do roku 1455 tvrzí a částečně vystupovalo z linie hradeb. Zřejmě na substrukci severní hradby předhradí a přilehlých stavení pak v raném baroku mohla vyrůst biskupská rezidence, jejíž vysoká trojpatrová hmota původní hrad od města pohledově dílem zakryla. 


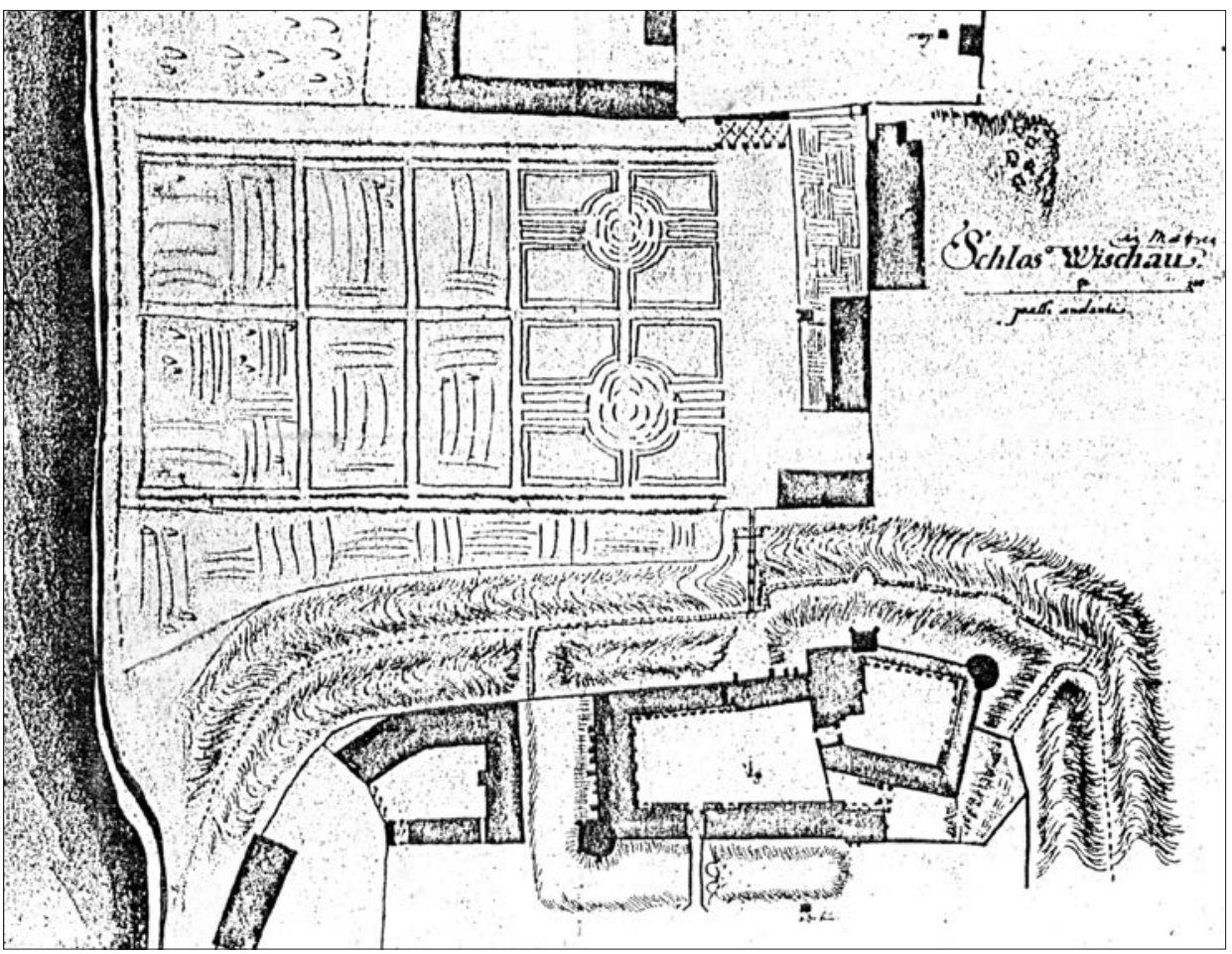

Obr. 13. Situační plán komplexu zámku z let 1710-1720. Zdroj Württembergische Landesbibliothek Stuttgart, Sammlung Nicolai, Bd. 146, Fol. 18.

Abb. 13. Lageplan des Schlosskomplexes aus den Jahren 1710-1720. Quelle Württembergische Landesbibliothek Stuttgart, Sammlung Nicolai, Bd. 146, Fol. 18.

Hrad od města, ale i od dvora (pivovaru) odděloval dvakrát zalomený, přes $20 \mathrm{~m}$ široký př́ikop, což platilo ještě v první čtvrtině 18. století (WLbS, Sammlung Nicolai, Bd. 146, Fol. 18r). Díky pozornosti, kterou sídlu biskup Tas z Boskovic věnoval, nabylo kvalit, takže už od roku 1460 se důsledně nazývalo hradem. Hrad tehdy měl věž s komnatou v patře (stuba superiori), horní velkou jizbu možná totožnou se společnou (communi) jizbou (přijímací síní?). O rok později se uvádí horní jizbička a nová otápěná síň (novo estuario). Roku 1465 se též uvádí velká (magno) síň, v roce 1467 se již vzpomíná nová palácová kaple, za pět let ještě nová otápěná horní síň v obytné části hradu a 1474 ještě dolní komnata - estuario inferiori (Lechner 1902/I, 73, 75, $79,83,86-88)$. Rozmístit četné interiéry nebylo možné bez využití i jiných budov než severního křídla a branské věže. Zřejmě už bylo k dispozici i východní křídlo, jež obsahovalo (pozdější?) kapli a s ní souběžný trakt s druhou věží v jeho západním nároží.

Biskup Tas zprvu stál na straně krále Jiřího z Kunštátu a Poděbrad, od něhož však v roce 1467 odpadl, a při dobytí města královským vojskem (1469) byl hrad vážně poškozen. Tas asi již rok nato přikročil k jeho obnově. Do roku 1472 ho zřejmě rozšíril o podélný trakt mezi kaplí a jižní věží a nelze ani vyloučit část zaniklého jižního křídla. Tasovu činnost dokládají kamenné desky s jeho erbem, druhé se znakem olomouckého biskupství a konečně třetí s erbem Šternberků (z nich vzešla Tasova matka Machna) jsou zazděné v čelní stěně zámku. Nelze vyloučit ani nějakou stavební činnost biskupa varadínského Jana Filipce, jehož za správce biskupství (1482-1496) ještě prosadil spoluvládce Moravy a uherský král Matyáš Korvín (Kalous 2009, 217, 219, 187). Pilným stavebníkem byl nepochybně i Stanislav Thurzo z Bethlenfalvy (spišské Betlanovce - 1497-1540), jenž se od počátku svého episkopátu přikláněl k uplatňování renesance. Avšak aktivitu směřoval hlavně na Kroměřiž, jejíž hrad po uvolnění za zástavy úplně přestavěl 
(srov. Hlobil-Petrů 1992, 129-150; Baletka 2004, 37-40; Samek 1999, 222). Tehdy progresivní orientace ve Vyškově potvrzuje Thurzova znaková kartuše v neúplné edikule umístěné nad portálem průjezdu věžovité brány předhradí, o jejíž stavbu se zasloužil.

Nebyla to jediná Thurzova vyškovská akce. Jeho stavitelé se postarali o vybudování rozměrné bašty v nároží předhradí nebo spíše jakéhosi rondelu se dvěma podlažími a štěrbinovými stř́lnami v dochovaném prŕzemí. Jejich výstř̌elnice byly široké jen tak, aby umožnily použití ručních palných zbraní. Zdi objektu jsou natolik tenké, možná měl být původně vyplněn zeminou, a po změně projektu zpevnili zdi zvenčí pěti šikmými opěrnými pilíři a interiér zaklenuli kopulí s parabolickými výsečemi. Co se jádra týče, budovy gotického a raně renesančního původu se uchovaly především v dnešním severním a západním křídle a na těchto stranách tvoří vnější stěny budov původní masivní hradba. Obě křídla v nároží spojuje hranolový útvar širší než obě navazující kř́ídla. Patrně toto těleso rovněž patří mezi Thurzovy produkty a sklep klenutý stlačenou valenou klenbou navazuje na hodnotné pozdně gotické suterény severního křídla. Tyto sklepy jsou mimořádně dobře až intaktně dochované, a to i s několika tesanými portály a šikmými sklepními okénky. Přitom záklenky jejich výsečí působivě prostupují do vysokých valených a ve vrcholech lomených kleneb. Klenby jsou tak vzhledné a pevné, že př̀i vestavbě barokního schodiště v západní sekci křídla i kvůli jednotné podobě postižený díl klenby znovu vložili v původním tvaru.

Hmotou trojbokého východního břitu paláce prostupovalo ze sklepa až do patra vřetenové schodiště a z vedlejšího velkého sklepa se chodilo i do úzkého gotického sklípku pod nádvořím. Valený sklep se nachází též pod severním koncem západního vrcholně renesančního křídla (Eliáš 2005, 89, 90). Výrazné znaky pozdní gotiky se rovněž projevují v místnostech (zvýšeného) přízemí severního křídla. Původní úroveň nádvoří je mírně zvýšená a při památkové revitalizaci v 50. letech 20. století (1951-1954) se podařilo většinu gotických architektonických prvků odkrýt (portálky, ostění oken, krb) a přiznáním vhodně zakomponovat do interiéru (Zháněl 1954). Obnova se naštěstí obešla bez rádoby romantických či puristických zásahů, nebot' kamenické články zůstaly na původních místech, ovšem strukturu zdiva zakryla omítka. Úpravy pro muzeální účely vyloučily násilné osazování volně a v sutích nalezených detailů, které se staly součástí expozic. Vzdálenost severního křídla od jižní hradby a jeho poměrně chráněná poloha rozhodly o tom, že právě ono se stalo hlavním palácem hradu. Stavebník ho přiložil k hradbě (1,8 m silné), jež oddělovala jádro hradu od města. V př́izemí čtyřprostorový palác biskup Thurzo doplnil zmíněným širším tělesem v nároží a asi nechal překlenout i ostatní místnosti. Kromě šneku v břitu vedlo chodbičkou v síle nádvorní zdi druhé schodiště do sklepa.

Na Thurzovo nárožní těleso se směrem k jihu podél gotické obvodní zdi (o tloušt'ce 2,1 m) připojilo renesanční kř́ídlo. Zed' je silnější kvůli tomu, že je vnější ohradou města. K této západní hradbě se podle historických plánů připojila městská hradba. Stavbu západního křídla inicioval bud' biskup Marek Khuen (1553-1565) nebo nanejvýš Vilém Prusinovský z Víckova (1565-1572; Válka 1995, 246). Z jejich episkopátů pocházejí i valené klenby př́izemí. Budova do své zvětšené hmoty pohltila pozdně gotickou nárožní okrouhlou baštu a předstoupila starší obvodní zed' do městského příkopu, ovšem tento rozměrný a dost masivní výstupek zaklenuli až v baroku. Tehdy asi přiložili k nádvorní zdi křídla otevřený arkádový ochoz klenutý na pilíře, který v patře nesl chodbu.

Patro prvotního paláce sice má obvodní zdi gotické, ale muzeem využitý interiér po požáru v roce 1917 úplně přestavěli a až roku 1948 odkryl stavitel F. Peška novověkou skořepinovou klenbu. Druhému patru starého paláce už část středověkých obvodních zdí chybí a vnitřek původně podstř̌šního charakteru při obnově upravili pro muzeum. Též patro západního křídla zabraly moderní pracovny muzea. Vše ostatní pozměnily přestavby nebo odstranily demolice. V předhradí, na nějakých starších substrukcích severní linie vyrostl raně barokní zámek a jinak zbyly jen starší objekty - zmíněná branská věž, rondel a větší díl východního kř́ídla, před likvidací rovněž podepřený početnými opěrnými pilíŕi.

Už indikační skica z roku 1826 (MZA, D 9, sign. 2496, kart. 591) i mapa stabilního katastru zaznamenaly zámek v podstatě v současné rozloze. Oproti dnešku na ní navíc figuruje jenom 
poloviční zbytek východního křídla jádra hradu. Avšak toto stavení, alespoň jeho východní podsklepený trakt, zachytil plán v díle Augusta Prokopa (1904/II, 537). Se severním palácem ho spojovala vysoká věžovitá brána, jíž se projíždělo z předhradí do jádra. Masivní zdivo věže odkryl nehluboko pod povrchem výkop z roku 2005 a z porovnání historických vyobrazení města vyplývá, že do výšky přilehlých stavení ji snížili mezi lety 1728 a 1736. Úplně byla odstraněna na počátku 19. století. Jižní konec křídla obsahoval kapli, nad jejíž střechu čněl sanktusník. Křídlo bylo na začátku 18. století širší, ale o západní podélný trakt přišlo snad po požáru v roce 1753. Už zúžené křídlo okolo roku 1800 nakreslil na pohledu na zámek od jihu stavitel Josef Haupt (Baarová 2006, 290; ZAO, pob. Olomouc, fond ÚŘAS, i. č. 56304, poř. č. 14514; srov. Eliáš 2005, 66).

Důležitou roli v opevnění města hrálo jižní křídlo gotického jádra, součást hradebního pásu, které zbourali mezi začátkem 19. století a rokem 1826, protože na indikační skice už chybí. Krom široké, byt' nevysoké věže vetknuté v mírném zlomu hradby do příkopu vzniklo úzké kř́ídlo jednorázově a jeho nádvorní strana se po celé délce otevírala klenutou chodbou. Kř́́dlem, resp. jeho vraty se od pozdního baroku dalo vyjít na stezku přes šíji mezi prríkopy ke kapucínskému klášteru. Věž byla nejméně dvoupatrová a patrně obytná, opěráky nakoso postavené v jejích nárožích naznačují prameny předpokládaný pozdně gotický původ. Přítomnost věže na Hauptově kresbě kolem roku 1800 napovídá, že byla s jižním křídlem odstraněna brzy poté. Stejně dopadla zástavba na jižní straně předhradí. Budova přiléhající štítem k hradnímu jádru byla patrová, a podle opěrných piliŕư může pocházet ještě z episkopátu Stanislava Thurza. Navazující přízemní stavení zase v nádvoří provázel arkádový čtvrttrakt. Rovněž z tohoto objektu se procházelo na dlouhou lávku přes vnější příkop do renesančních zahrad. Jako poslední v předhradí padlo východní stavení, které zmizelo už před rokem 1858 (Eliáš 2005, 77).

Opevnění města Vyškova a s ním spojeného vrchnostenského areálu sice z převažující části zaniklo, ale díky několika historickým plánům a vedutám je jeho rozvrh, a nakonec i rámcový vývoj, spolehlivě poznatelný. Kupodivu je to možné i bez náročných archeologických výzkumů. Platí to jen pro nemnoho menších měst, jejichž fortifikace téměř zmizely, ovšem tam, kde jejich zbytky úplně chybí, nebo byl jejich urbanismus hrubě narušen, bude podpovrchový průzkum absolutní nutností.

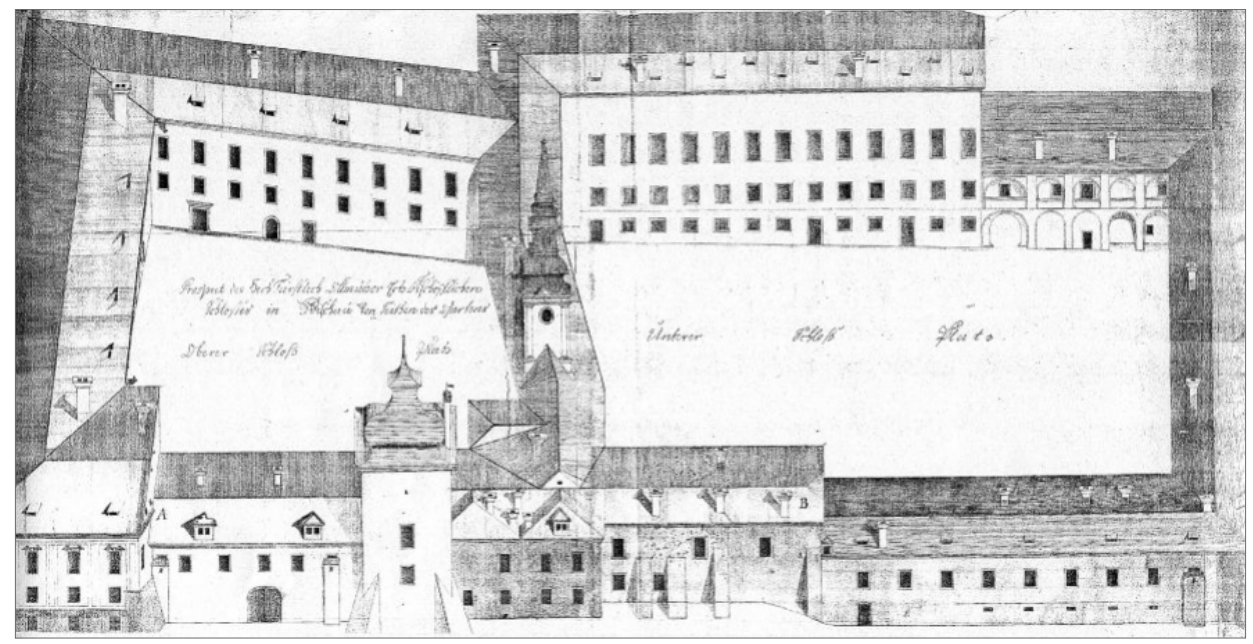

Obr. 14. Kavalírní pohled na zámek od jihu snad z počátku 19. století, nakreslil Josef Haupt. Podle Eliáš 2005 , 66. Abb. 14. Kavalier-Projektion des Schlosses, wahrscheinlich Anfang 19. Jhdt., gezeichnet von Josef Haupt. Nach Eliáš 2005, 66 . 


\section{Prameny a literatura}

Archiv města Brna (AMB), sbírka D. J. I. Hoffera, sign. 39/122.

BAAROVÁ, Z., 2003: Vyškov (okr. Vyškov). Intravilán, zámek, město, PV 44, 284.

- 2006: Vyškov (okr. Vyškov). Ul. Radnická č. 2; Vyškov (okr. Vyškov). Husova ul. 4; Zámek, PV 47 , 289-290.

BALETKA, T., 2004: Dvůr olomouckého biskupa Stanislava Thurza (1497-1540), jeho kancelář a správa biskupských statků, Sborník archivních prací LIV, 3-236.

BORSKÝ, P.-ČERNOUŠKOVÁ, D., 2001: Kostel Nanebevzetí Panny Marie ve Vyškově, PRP 8, č. 2 , $122-132$.

BURIAN, V., 1975: Středověká silnice mezi Vyškovem a Slavkovem. In: 80 let muzejní práce na Vyškovsku, 105-109. Brno - Vyškov.

CDB I, II: Codex diplomaticus et epistolaris regni Bohemiae I (805-1197), II (1198-1230) (Friedrich, G., ed.). Pragae 1904-1907, 1912.

CDB IV/1, V/2, V/3: Codex diplomaticus et epistolaris regni Bohemiae (1241-1253), V/2 (1267-1278), V/3 (1253-1278) (Šebánek, J.-Dušková, S., edd.). Pragae 1962, 1981, 1982.

CDM VI: Codex diplomaticus et epistolaris Moraviae VI (1307-1333) (Chlumecký, P. R. v.-Chytil, J., edd.). Brünn 1854.

CDM X: Codex diplomaticus et epistolaris Moraviae X (1367-1375) (Brandl, V., ed.). Brünn 1878.

DOLEŽEL, J., 1995: Ke vzniku a vývoji několika měst střední a severozápadní Moravy (Blansko, Ivančice, Tišnov, Velká Bíteš, Vyškov) - Zur Entstehung und Entwicklung einiger Städte in Mittel- und Nordwestmähren (Blansko, Ivančice, Tišnov, Velká Bíteš, Vyškov), AH 20, 201-217.

ELIÁŠ, J., 2004: Nástin historického a architektonického vývoje vyškovského náměstí ve světle SHP sídelního útvaru. In: 110 let muzejní práce na Vyškovsku, 61-68. Vyškov.

- 2005: Zámek Vyškov. Sklepy a přízemí tzv. Starého zámku. Podrobný povrchový SHP. Brno, computeropis ulož. na MěÚ Vyškov.

FRANKENBERGER, O., 1960: Husitské válečnictví po Lipanech. Praha.

HLOBIL, I.-PETRŮ, E., 1992: Humanismus a raná renesance na Moravě. Praha.

JEŘÁBKOVÁ, Z., 1999: Vyškov. In: Od gotiky k renesanci. Výtvarná kultura Moravy a Slezska 1400-1550, III. Olomoucko (Hlobil, I.-Perůtka, M., edd.), 250. Olomouc.

KALOUS, A., 2009: Matyáš Korvín (1443-1490). Uherský a český král. České Budějovice.

KRAFL, P., 2000: Vyškovská synodální statuta (1413), PHS 35, 67-83.

KRONES, F. v., 1900: Die erzählenden Quellen der Geschichte Mährens im fünfzehnten Jahrhunderts, Zeitschrift des deutschen Vereines für die Geschichte Mährens und Schlesiens 4, 1-105.

KUČA, K., 2011: Města a městečka v Čechách na Moravě a ve Slezsku VIII. V-Ž. Praha.

LECHNER, K., ed., 1902: Die ältesten Belehnungs- und Lehensgerichtsbücher. Brünn.

LORRAINE, de Ch., 1749: Relation de la Campagne de Moravie et de Boheme, ulož. v Österreichisches Staatsarchiv Wien, Kriegsarchiv, sign. H IIIe.

MEZNÍK, J., 1999: Lucemburská Morava (1310-1423). Praha.

MIKULKOVÁ, B., 2008: Vyškov (okr. Vyškov). Kostelní ulice, PV 49, 457.

MLATEČEK, K., 2009: Vyškov na počátku 15. století. In: Campana Codex Civitas. Miroslao Flodr Octogenario, 308-321. Brno.

Moravský zemský archiv (MZA) Brno, D 9 Indikační skici.

NEKUDA, V., ed., 1965: Vlastivěda moravská. Vyškovsko. Brno.

PAPROCKÝ 1993: Paprocký z Glogol a z Paprocké Woly, B., Zrcadlo slawného Markgrabství Morawského. Ostrava.

PEŘINKA, F., 1911: Kroměřížský okres. Vlastivěda moravská. I. část. Brno.

PROKOP, A., 1904: Die Markgrafschaft Mähren in kunstgeschichtlicher Beziehung II. Wien.

RYBÁŘOVÁ, K., 2013: Vyškov (okr. Vyškov). Náměstí Čsl. armády 112/1, PV 54/2, 289-290.

SAMEK, B., 1999: Umělecké památky Moravy a Slezska 2 [J-N]. Praha.

SMUTNÝ, B., 2009: Inspekce opevnění měst na Moravě v roce 1778. In: XXX. Mikulovské sympozium 2008. Hranice na jižní Moravě a její obrana od doby římské, 211-226. Brno.

SOkA Vyškov ve Slavkově u Brna, fond AMV I, kart. 477.

VÁLKA, J., 1995: Dějiny Moravy 2. Morava reformace, renesance a baroka. Brno.

Württembergische Landesbibliothek Stuttgart (WLbS), Sammlung Nicolai, Bd. 146.

Zemský archiv Opava (ZAO), pobočka Olomouc, fond Ústřední ředitelství arcibiskupských statků (ÚŘAS).

ZHÁNĚL, J., 1954: Oprava zámku ve Vyškově, ZPP 14, 144-146.

- 1967: Biskupský hrad Melice II. Zprávy Vlastivědného muzea ve Vyškově č. 72. Vyškov. 


\section{Zusammenfassung}

\section{Anmerkungen zur Befestigung der Stadt Vyškov}

Im herzöglichen Vyškov (Wischau) gehörte in den Jahren 1131/1141 ein Aratrum zum Wenzelsdom in Olmütz. Verwalter im Jahr 1201 war ein Comes Jakub, der offenbar auf einem leicht eingefriedeten Herrenhof seinen Sitz hatte, und am Zusammenfluss der Haná (Hanna) mit zwei Bächen wuchs die Siedlung Vyškov heran. Da es aus dem älteren 13. Jahrhundert keine Funde gibt, befand sich ihr Vorgänger wohl woanders. Der Weg durch die Wischauer Pforte führte früher am Fuß des Drahaner Berglandes entlang, und erst nach dem Jahr 1200 entstand an einer jüngeren Weggabelung ein dreieckiger Marktplatz. Das Dorf Brňany (Bründlitz) und ihre Pfarrkirche könnten älter sein, zwischen dieser Gemeinde und Vyškov erstreckte sich bereits im Jahr 1277 ein Fischteich. Im Jahr 1267 ist Vyškov bereits eine kleine Stadt, auf dessen Marktplatz eine Kirche stand. Von Bischof Bruno wurde sie wohl vor dem Jahr 1248 zur Stadt erhöht, als er das Gebiet von Wenzel II. erhielt. Die Fläche mit Schloss und Bierbrauerei gehörte nicht zur Siedlung. Dort stand im Jahr 1267 wohl ein Herrenhof, vielleicht derjenige, welcher im Jahr 1394 direkt vor der im Jahr 1367 erwähnten Stadt lag. Damals konnte sie von Brettern und einem Graben umfriedet gewesen sein. Beim Wiederaufbau der von den Hussiten zerstörten Stadt (1423) kam es zum Bau einer einfachen Stadtmauer mit drei Toren und einer Burg, die bereits 1449 zur Verwaltung des Lehnsbezirks diente. Die Bauten wurden von Bischof Protasius von Boskowitz vollendet, der auch eine neue Kirche errichtete. Im Jahr 1469 wurde die Stadt erneut zerstört, was sie Mikuláš Střela, einem Hauptmann von König Georg von Podiebrad zu verdanken hat. Ihr Wiederaufbau dauerte bis zum Jahr 1496.

Das Areal der Stadt wurde vom Flusslauf der Haná, dem Fischteich und einem Geländebruch im Westen umschlossen, und die Vorstadt hat sich erst im 19. Jahrhundert gebildet. Eine Ausnahme war der sogenannte Rasen mit dem St. Annenspital. Die Stadtmauer verband den südlichen Abschnitt mit Burg und Hof (Brauerei) mit dem Stadtkern. Die Fläche innerhalb der Stadtmauer beträgt 9,0 ha. Die aus sorgfältig aufeinander geschichteten Steinen bestehende Stadtmauer hat die Stadt weich umspannt, ist aber nur teilweise erhalten geblieben. Sie war 5-6 m hoch und 1,6 m stark, und hat im 19. Jahrhundert den Aufschwung behindert, sodass sie in den Jahren 1834-1843 mit allen drei Toren abgerissen wurde. Aussehen und Aufbau der Befestigung wird auf einer Reihe von historischen Darstellungen wiedergegeben. Die Tore öffneten sich in Prismentürmen mit Fallbrücken und waren um ein Vortor ergänzt, das beim Olmützer Tor einer Barbakane nahekam. Sonstige Türme kamen in der Stadtmauer keine vor. Außen wurde die Stadtmauer zunächst von einem Graben und einem Wall umsäumt, der Graben wurde später teilweise verdoppelt. Ein Zwinger fehlte, jedoch wurde ein zweiter Befestigungsring auf einer älteren Aufschüttung teilweise erst in der Neuzeit realisiert. Aus der Befestigungslinie traten flankierende Elemente hervor. Gleichzeitig zur Barbakane des Olmützer Tors entstand in der Nordecke ein gemauertes Rondell (mit einem Durchmesser von ca. 17-18 m). Das Rondell figuriert noch auf einem Plan aus dem Jahr 1778, am genauesten sind die Pläne von F. F. v. Nicolaie und Ch. de Lorraine.

Knapp erwähnt sei das Schlossensemble. Im Jahr 1449 hatte die Burg bereits als Ersatz für das von Rittern aus Moravany belagerte Kremsier gedient. Die Stadtmauer war damals bereits mit dem Turm des Brünner Tors verbunden. Beachtung wurde der Burg besonders von Protasius von Boskowitz entgegengebracht, der von König Georg abfiel und sich nach der 1469 erfolgten Einnahme von Vyškov um ihren Wiederaufbau gekümmert hat. Der spätgotische Sitz war zweiteilig - an die ältere Kernburg $(65 \times 43 \mathrm{~m})$ schloss eine im Renaissancestil umgebaute Vorburg an. Auf dem Grundbau ihrer nördlichen Stadtmauer hatte im Frühbarock die Bischofsresidenz wachsen können. Die Burg war noch Anfang des 18. Jahrhunderts durch einen $20 \mathrm{~m}$ breiten Graben von der Umgebung getrennt. Im Jahr 1460 hatte sie einen Palas, einen Wohn- und einen Torturm und im Ostflügel die spätere Kapelle. Am Aussehen der Burg hatte auch Bischof Stanislaus Thurzo seinen Anteil (Westflügel, Tor und Bastei - Rondell der Vorburg), der eine 
Orientierung an der Renaissance nach Vyškov brachte. Auch seine Nachfolger haben diesen Stil beibehalten, um die Residenz hat sich jedoch Karl II. von Liechtenstein-Kastelkorn gekümmert. Der Beginn des 19. Jahrhunderts war für das Schloss schicksalhaft, damals wurde das meiste abgerissen, ein Rest wurde durch die um Mitte des 20. Jahrhunderts erfolgte Revitalisierung von Denkmälern gerettet.

Die Befestigung der Stadt Vyškov und des mit ihr verbundenen herrschaftlichen Areals ist überwiegend zwar verschwunden, jedoch lassen sich ihr Verlauf und ihre grobe Entwicklung anhand von historischen Plänen und Stadtansichten rekonstruieren. Eventuelle archäologische Grabungen können hier zu einer Präzisierung einen weiteren Beitrag leisten.

Doc. Ing. PhDr. Miroslav Plaček, Ústav archeologie a muzeologie Filozofické fakulty Masarykovy univerzity, Arna Nováka 1, 60200 Brno, Česká republika, mplaczek@seznam.cz 
